\title{
Implementation of Legal Certainty on Comparative Studies of Ijarah Muntahiya Bittamlik \& Rental Contract
}

\author{
Mohammad Nurul Huda*) and Muhammad Ridwan Lubis**)
}

*) Universitas Islam Negeri Semarang, Email: nurulhuda261295@gmail.com

**) Universitas Muslim Nusantara Al Washliyah Medan, Email: muhammadridwanlubis76@gmail.com

\begin{abstract}
In recent times, it has become common among the public regarding the Ijarah Muntahiya Bittamlik (IMBT) contract. IMBT is a contract similar to a lease and purchase agreement. In practice in the community, these two contracts are carried out by means of renting first and ending with buying and selling. Although, in general they have similarities, these two agreements have differences that have different consequences. The research method used in this study is doctrinal legal research with a comparative law approach. The results of this study indicate that the IMBT contract has more legal certainty than the lease-purchase agreement. This is because the IMBT contract has provisions regulated in the Sharia Banking Law, the Sharia Economic Law Compilation, and PSAK No. 107 concerning Ijarah and IMBT accounting, while the lease purchase agreement is only based on the principle of freedom of contract. The implementation of the IMBT contract also has more legal certainty, considering that dispute resolution efforts can be carried out through the provisions of Article 283 and Article 284 of the KHES by carrying out sales of the disputed object. This is different from a lease-purchase agreement, where dispute resolution efforts are generally carried out through unilateral withdrawals and the agreement also contains standard clauses that have the potential to violate Article 18 of the Consumer Protection Law.
\end{abstract}

Keywords: IMBT; Rental; Contract; Legal Certainty.

\section{INTRODUCTION}

Pancasila and the 1945 Constitution of the Republic of Indonesia have mandated that the goal of national development is the creation of a just and prosperous society based on economic democracy by developing an economic system that is based on a just market mechanism. ${ }^{1}$

\footnotetext{
${ }^{1}$ Sentiya Dwi Ningsih, Peran Notaris Dalam Pelaksanaan Pembuatan Akta Akad Pembiayaan Di Bank Syariah Menurut Undang-Undang Nomor 2 Tahun 2014 Tentang Jabatan Notaris, Jurnal Akta Vol. 4. No. 1, March 2017, p.79-82
} 
Since the enactment of the Sharia Banking Act No. 10 of 1998 as a replacement for Act No. 7 of 1992 concerning Bank Indonesia, which accommodates and encourages the widespread presence of Islamic banking. With the enactment of Act No. 10 of 1998 which stipulates the banking system in Indonesia as a dual banking system or a dual banking system (conventional and sharia), many conventional banks began to operate with their Sharia Business Units, and Islamic Commercial Banks began to appear. (BUS), of which there are now 11 BUS standing in Indonesia. Then was born Act No. 21 of 2008 concerning Islamic banking. ${ }^{2}$

In recent times, it has become common among the public regarding the Ijarah Muntahiya Bittamlik (IMBT) contract. By definition, an Ijarah Muntahiya Bittamlik is a lease agreement accompanied by an option to transfer ownership of an object being leased after the lease expires with a sale and purchase option or a grant. ${ }^{3}$ Referring to the Fatwa of DSN-MUI Number: 27/DSN-MUI/III/2003 concerning Ijarah Muntahiya Bittamlik in the provisions considering point a, it is stated that nowadays in society it is common to practice leasing, namely lease agreements accompanied by transfer options. The ownership rights to an object being leased, to the lessee after the end of the lease period. Furthermore, point $b$ also states that in order to meet the needs of Islamic Financial Institutions (LKS) requires a lease purchase agreement that is in accordance with sharia principles. Then point $c$ states that therefore, the National Sharia Council (DSN) deems it necessary to stipulate a fatwa regarding leases that are in accordance with sharia, namely the al-Ijarah Muntahiya Bittamlik contract or alIjarah wa al-iqtina'to be used as a guideline. ${ }^{4}$

Based on several points of consideration, then the emergence of the Ijarah Muntahiya Bittamlik contract actually cannot be separated from the development of the practice of buying and selling which has occurred a lot in the community. However, because the principle of this lease-purchase agreement is based on the conventional economic system, it is deemed necessary to stipulate new provisions regarding the leasepurchase agreement in accordance with sharia principles. In this context, a lease purchase agreement is defined as an agreement in which the payment method is to be paid in installments several times and as long as the installment of an item has not been paid in full, the buyer's position is still considered a tenant and will change ownership after the settlement period is complete. ${ }^{5}$

The definition of Ijarah Muntahiya Bittamlik and lease-purchase as described above, of course, has almost the same thing, considering that the Ijarah vomiting-bittamlik contract has begun to emerge because there have been many rental-purchase practices that have been carried out by the community. Even though by definition the Ijarah Muntahiya Bittamlik contract and the lease-purchase agreement are almost the same, of course there are some differences that become an important part in the implementation of the two agreements. Moreover, in the implementation and legal consequences, both have specific principles and provisions which result in these two

\footnotetext{
2 Husna Ni'matul Ulya, Penerapan Akad Ijarah Muntahiya Bittamlik (IMBT) Pada Transaksi Lembaga Keuangan Syariah, El-Wasathiya: Jurnal Studi Agama, Volume 6, Nomor 1, June 2018, p. 21-37

3Muhammad Syafi'i Antonio, Bank Syariah dari Teori ke Praktik, Gema Insani, Jakarta, p. 118. ${ }^{4}$ Fatwa DSN-MUI No. 27/DSN-MUI/III/2002 on al-Ijarah Muntahiya bi al-Tamlik.

${ }^{5}$ Sandrina Wijaya, Surat Perjanjian Bisnis Langsung Deal, Penerbit Pustaka Grathama, Yogyakarta, 2009, p. 18.
} 
agreements having their respective advantages and disadvantages. Based on this fact, it is deemed necessary to conduct a comparative study, considering that these two agreements have grown and developed in the realm of society. Furthermore, this comparison also aims to find out the advantages and disadvantages of each agreement, as well as which agreement should be more optimized, because it guarantees more legal certainty and protection for business actors and consumers. Moreover, considering that the implementation of these two agreements is also often carried out with standard agreements, it is very necessary to carry out this comparative study to find out more about which agreements should be more optimized by the community. Because it guarantees more certainty and legal protection for business actors and consumers. Moreover, considering that the implementation of these two agreements is also often carried out with standard agreements, it is very necessary to carry out this comparative study to find out more about which agreements should be more optimized by the community. Because it guarantees more certainty and legal protection for business actors and consumers. Moreover, considering that the implementation of these two agreements is also often carried out with standard agreements, it is very necessary to carry out this comparative study to find out more about which agreements should be more optimized by the community.

\section{RESEARCH METHODS}

The research method used in this research is normative legal research or doctrinal legal research. Soerjono Soekanto defines normative legal research as a series of legal research conducted by examining library materials or secondary data as the basic material to be researched by conducting a search on regulations and literature related to the problems studied. ${ }^{6}$ While the approach used in this research is comparative law. Research on comparative law is conducted to find out how the similarities and differences between two or more different laws are. In addition, legal comparisons can also be made to find out the legal rules of two or more legal systems that regulate the same thing. ${ }^{7}$

\section{RESULTS AND DISCUSSION \\ Comparative Study of the Muntahiya Bittamlik Ijarah Contract and Lease Purchase Agreement}

Ijarah Muntahiya Bittamlik (IMBT) is a combination of Ijarah (lease) and ba'i (sale and purchase) or grant contracts. ${ }^{8}$ The implementation of the IMBT contract is almost like a lease-purchase agreement that has developed in the community. The similarity to the IMBT contract and the lease purchase agreement lies in the ownership effort at the end of the lease period, by conducting a sale and purchase transaction. As explained above, the emergence of the IMBT contract is due to the implementation of many conventional lease-purchase agreements.

Based on the explanation of Article 19 paragraph (1) of the Sharia Banking Law, what is meant by an Ijarah Muntahiya Bittamlik contract is a contract for the provision of funds in the context of transferring the rights or benefits of an item or service based

\footnotetext{
${ }^{6}$ Soerjono Soekanto and Sri Mamudji, Penelitian Hukum Normatif (Suatu Tinjauan Singkat), Rajawali Pers, Jakarta, 2001, p. 13.

${ }^{7}$ Nurul Qamar, Muhammad Syarif, dan Dachtran S. Busthami, Metode Penelitian Hukum (Legal Research Methods), Cv. Social Politics Genius, Makassar, 2017, p. 51.

${ }^{8}$ Ascarya, Akad dan Produk Bank Syariah, Prt. Fifth, Raja Grafindo Persada, Jakarta, 2015, p. 224.
} 
on a lease transaction with the option of transferring ownership of the goods. Ijarah Muntahiya Bittamlik financing is a form of business activity for a sharia bank or sharia financial institution that is carried out based on sharia principles. ${ }^{9}$ The implementation of the lease-purchase agreement that has developed in the community has resulted in the National Sharia Council issuing lease-purchase provisions in accordance with sharia principles. Although viewed from a historical perspective, the emergence of the IMBT contract cannot be separated from the implementation of the lease purchase agreement, but the provisions contained in it certainly have different principles and implementation. This fact is not only seen in terms of the interest principle and sharia provisions used by each agreement, but also in terms of the definitions and several principles that should be upheld by civil law in Indonesia.

Habsi Ramli in this case defines the IMBT contract as a lease agreement between the owner of the leased object and the lessee to obtain compensation for the leased object with the option of transferring ownership of the leased object at a certain time in accordance with the sale and purchase agreement or grant. ${ }^{10}$ In line with that, AsySyamil also describes the IMBT contract as an agreement made by an Islamic bank to rent goods to someone for a certain time, sometimes the credit price is higher than the normal price, so that the tenant can own the object for rent after the lease expires. If the tenant pays the rent, the rented item will become the property of the tenant with a grant contract or the last installment is likened to buying and selling money for the rented item. ${ }^{11}$ Furthermore, Abdul Aziz Khalifah al-Qishar stated that the Ijarah Muntahiya Bittamliktamliik contract was:

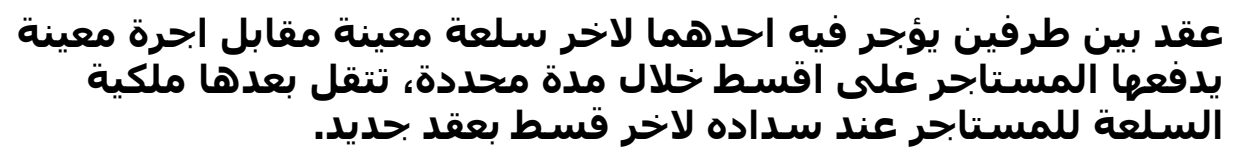

Which means: A contract entered into between two parties, where one party rents a commodity of goods to the other party in exchange for a certain fee paid by the tenant in installments over a certain period, after the last payment is made, ownership occurs with a new contract. ${ }^{12}$

Implementation IMBT contract is preceded by ( $\left.w a^{\prime} d\right)$ promise to transfer ownership at the end of the lease term. DSN Fatwa No. 85/DSN-MUI/XII/2012 concerning Wa'ad in Sharia Financial Transactions defines wa'd as a statement of the will of a person or one party to do something good (or not do something bad) to another party (mau'ud) in the future. Furthermore, Abdul Manan also defines a promise as a desire expressed by someone to do something, either deed or speech with the aim of providing benefits to the other party. ${ }^{13}$ Furthermore, Syaif Rajab al-Muqazil also stated that the meaning of wa'd is:

\footnotetext{
${ }^{9}$ Ahmad Khoirin Andi, Ijarah Muntahiya Bittamlik Sebagai Solusi Ekonomi Kerakyatan, ACTIVA: Jurnal Ekonomi Syariah, Volume 2 Nomor 22 October 2019, p.22-43

${ }^{10}$ Hasbi Ramli, Teori Dasar Akuntansi Syariah, Renaisan, Jakarta 2005, p. 63.

${ }^{11}$ Mahmud Abdul Karim Ahmad Irsyid, As-Syamil Fi Muamalat Wa amaliyatil Masharif alIslamiyah, Darun Nafais, Jordania, 2007, p. 63.

${ }^{12}$ Abdul Aziz Khalifah al-Qishar, al-Ijarah Ma'aa Wa'du bi al-Tamlik li al-Dhihaabi wa al-Fidhdhah, (Kulliyatul al-Syariah, Jami'atul Kuwait, n.y), p. 4.

${ }^{13}$ Abdul Manan, Hukum Ekonomi Syariah: Dalam Perspektif Kewenangan Peradilan Agama, prt. Fouth, (Jakarta: Kancana, 2016), p. 73.
} 
Which means: a promise is an agreement in which one or both of the contracting persons promise to perform a certain contract in the future. ${ }^{14}$

The legal consequences of $w a^{\prime} d$ in the view of scholars are also differences of opinion regarding whether or not wa'd is permissible. The majority of Fuqaha from Hanafiyah, Syafiiyah, Hanabilah and one opinion from Malikiyah say that a promise is a religious obligation (mulzimun diniyah) and not a formal legal obligation (ghair mulzin qadhaam), because wa'ad is a tabarru' contract and a tabarru' contract is not customary or binding. . While the opinions of some scholars include Ibn Shubrumah, Ishaq bin Rawahiyah, Hasan Basri and some of the Malikiyah opinions state that the promise must be fulfilled and legally binding. ${ }^{15}$ This difference of opinion does not only occur in the views of the ulama, but in the DSN-MUI fatwa there has also been a change in the legal consequences of wa'd which are not binding into mulzim and must be carried out. This is based on Article 2 of the DSN Fatwa No. 27/DSN-MUI/III/2002 concerning Al-Ijarah al-Muntahiya Bi al-Tamlik which states that the promise to transfer ownership in the IMBT contract is a wa'd or promise which is not legally binding. ${ }^{16}$ Furthermore, DSN Fatwa No. 85/DSN-MUI/XII/2012 concerning Promises ( $W a^{\prime} d$ ) in Sharia Financial and Business Transactions in 2012 which states that promises ( $w a^{\prime} d$ ) in sharia financial and business transactions are mulzim or mandatory to be fulfilled by wa'id by following the provisions contained in this fatwa. Based on this provision, it is in accordance with Article 1338 of the Civil Code which states that "all agreements made legally apply as law for those who make them. An agreement cannot be withdrawn other than with the agreement of both parties, or for reasons which are stated to be sufficient by law." Other than that, Article 1339 of the Civil Code also states that an agreement made is not only binding on things that are expressly stated in it, but also for everything which according to the nature of the agreement is required by propriety, custom and law. In addition, the provisions regarding the IMBT contract are also regulated in the Sharia Economic Law Commission (KHES).

Unlike the case with IMBT, which has experienced a uniform definition, legal experts have different views on the definition of lease and purchase. There are at least three views on the meaning of leasing. Are as follows: ${ }^{17}$

a. The first definition argues that buying and selling leases is the same as buying and selling installments.

b. The second definition holds that leasing is the same as leasing.

c. The third definition argues that leasing is a mixture between the act of leasing and the act of buying and selling.

\footnotetext{
${ }^{14}$ Syaif Rajab Qazamil, al-Wa'du Bi al-Ta'aaqid (Diraasah Muqaaranah Baina al-Syariiati wa alQanuun), PDF, p. 5.

${ }^{15}$ Panji Adam Agus Putra, Konsep Wa'ad dan Implementasinya dalam Fatwa Dewan Syariah Nasional Majelis Ulama Indonesia, Amwaluna; Jurnal Ekonomi dan Keuangan Syariah, Vol. 2, No. 2, p. 226.

16Jaih Mubarok, Fikih Mu'amalah Maliyah Akad Ijarah dan Jualah, Simbosa Rekatama Media, Bandung, 2017, p. 106.

${ }^{17}$ Salim H.S., Perkembangan Hukum Kontrak Innominate di Indonesia, Prt. 11, Sinar Grafika, Jakarta, p. 128.
} 
The view of the lease purchase which is the same as the sale and purchase of installments refers to Sandrina Wijaya's view which states that the lease purchase agreement is an agreement in which the payment method is to be paid in installments several times and as long as the installment of an item has not been paid in full, the position of the buyer is still considered a tenant and will change ownership after repayment period. ${ }^{18}$

Meanwhile, a lease purchase which is equated with a lease refers to the Hire Purchast Act 1965 which states that a lease purchase is a lease agreement with an option from the lessee to purchase the leased goods. Furthermore, the view of lease-purchase which is the same as leasing is also in line with the opinion of Wirjono Prodjodikoro which states that a lease-purchase is essentially an agreement to lease goods with the result that the recipient does not become the owner, but only the user. Only when the rent has been paid in a certain amount with the purchase price, then the position of the tenant then changes to the buyer, so that the leased goods become his property. ${ }^{19}$ While the lease purchase is a mixture between the act of renting and buying and selling based on the view of R. Soebekti which states that "a lease purchase agreement is actually a practice of buying and selling, at least this agreement is closer to an act of buying and selling compared to an act of leasing, even though the act of leasing is buying is a mixture of the two." 20

The existence of different definitions of lease and purchase as explained above will certainly cause legal uncertainty, considering that equating a lease purchase agreement with a sale and purchase of installments, leasing, or mixing leases and buying and selling of course has different legal consequences. The definition of a lease purchase agreement which is equated with a sale and purchase of installments has the consequence that there has been a transfer of ownership and control at the beginning when the sale and purchase of installments is agreed by both parties. The discussion regarding payment by installments is an agreement that has been agreed by both parties. $^{21}$

The lease purchase agreement which is equated with the lease will result in the transfer of ownership only, without any transfer of ownership. This refers to Article 1548 of the Civil Code which states that "lease is an agreement in which one party binds himself to provide the other party with the enjoyment of an item for a certain period of time and with payment of a price which the party has later agreed to pay."22 While the lease purchase agreement is equated with a mixture of lease and purchase, it will create legal uncertainty, considering that these two agreements certainly have different legal consequences.

The legal uncertainty of the lease-purchase agreement is also increasingly visible, when there is no rule that overshadows the lease-purchase agreement, even though it is based on the principle of freedom of contract. Furthermore, this uncertainty is also

\footnotetext{
${ }^{18}$ Sandrina Wijaya, Surat Perjanjian Bisnis Langsung Deal, Op.cit, p. 18.

${ }^{19}$ Evi Ariyani, Hukum Perjanjian, Penerbit Ombak, Yogyakarta, 2013, p. 83.

${ }^{20}$ Salim H.S., Perkembangan Hukum Kontrak Innominate di Indonesia, Op.cit, p. 129.

${ }^{21} \mathrm{M}$ Munir Fuady, Hukum Bisnis dalam Teori dan Praktik Buku Ketiga, Prt. Third, Pt. Citra Aditya Bakti, Bandung, 2017, p. 256.

${ }^{22}$ Libertus Jaehani, Pedoman Praktis Membuat Surat Perjanjian Beserta Contoh-contohnya, Prt. Second, Visimedia, South Jakarta, 2007, p. 23.
} 
shown in the occurrence of unilateral withdrawals from business actors when the debtor defaults. The existence of unilateral withdrawal of the object of leasing like this at least provides an illustration of the injustice of the legal consequences arising from the lease and purchase agreement. This is because before the repayment period of the goods occurs, the buyer is still considered indebted to the business actor. This view is based on one of the clauses in the general lease agreement which states that "The total amount of money as much as ...... is considered as a debt of the second party." It is just, if there is a default due to the buyer's negligence in making installments, then all the installments which were originally referred to as debts will be considered as rent, so that business actors can make unilateral withdrawals on the basis that the vehicle rental period has ended. This is based on the clause "In the event of cancellation of this agreement, all payments from the second party to the first party are considered as rent for the use of the vehicle." The consequences of the leasepurchase agreement that change from payment of debt to payment of rent as such, of course provide uncertainty on the legal consequences arising from the lease-purchase agreement. This is, of course, different from the settlement in the Ijarah Muntahiya Bittamlik contract, when there is a default by the buyer:

a. The mu'jir/leasing party can settle the Ijarah Muntiyah bittamlik contract for the musta'jir/tenant who is unable to repay the financing within the agreed period.

b. The settlement as referred to in paragraph (1) can be settled through reconciliation and/or court.

Furthermore, Article 284 also states that the court may decide to sell the object of Ijarah mutahiya bittamlik that cannot be repaid by the tenant at market prices to pay off the debt of the tenant.

Regardless of the context, the legal basis used as the basis for the implementation of the IMBT contract is Article 19 of the Law of the Republic of Indonesia No. 21 of 2008 concerning Islamic Banking. Provisions regarding IMBT are also regulated in Article 208 of the Sharia Economic Law. In addition, the provisions for dealing with the Ijarah Muntahiya Bittamlik contract are also regulated in PSAK No. 107 on Ijarah accounting and Ijarah Muntahiya Bittamlik.

In contrast to the case of the Ijarah Muntahiya Bittamlik contract, the lease-purchase agreement in Indonesian positive law was basically only known after the issuance of the Decree of the Minister of Trade and Cooperatives No. 34/KP/II/1980 dated February 1, 1980 concerning Licensing for Hire Purchase, Sale and Purchase in Installments, and Rent (Renteng). However, to encourage the creation of a conducive and efficient business climate, several licensing and registration provisions are regulated in the Decree of the Minister of Trade and Cooperatives No. 34/KP/II/1980 concerning Licenses for Hire Purchase, Sale and Purchase in Installments, and Rent (Renteng) are abolished. This is based on the Regulation of the Minister of Trade of the Republic of Indonesia Number: ${ }^{23}$ The revocation of the provisions governing the lease-purchase agreement has resulted in the absence of regulations that specifically regulate the lease-purchase agreement. The absence of provisions governing the lease purchase agreement resulted in this agreement being born based on the principle of freedom of contract. In this case, the principle of freedom of contract is regulated in Article 1338 paragraph (1) of the Civil Code. Article 1338 paragraph (1) of the Civil

\footnotetext{
23Jeinal Bawarodi, Penerapan Perjanjian Sewa Beli di Indonesia dan Akibat Hukumnya, Lex Privatum, Vol. II, No. 3, 2014, p. 11.
} 
Code explains that every individual may enter into any agreement, anytime, and anywhere as long as it fulfills the legal requirements of the agreement and does not conflict with applicable law in Indonesia. ${ }^{24}$

In the context of the implementation of the IMBT contract and the lease purchase agreement, both use standard agreements, so that the contents of the agreement have been made from the beginning by business actors without involving the buyer. In this context, Sutan Remi Sjahdeini defines a standard agreement as an agreement in which almost all of the clauses are standardized by the user and the other party does not have the opportunity to negotiate or request changes to the agreement. ${ }^{25}$ In line with that, Mertokusumo also defines a standard agreement as an agreement whose contents are determined a priori by the authorities or individuals who generally have a stronger or more economically or psychologically superior position than the opposing party. ${ }^{26}$ Of course, in the implementation of the lease-purchase agreement and IMBT, this results in an unbalanced bargaining position, so that the contents of the agreement better protect the interests of business actors. Although the potential in the lease purchase agreement and IMBT contract is to use such a standard agreement, this provision may be carried out as long as it does not conflict with Article 18 of Act No. 8 of 1999 concerning Consumer Protection. The contents of Article 18 are as follows:

1. Business actors are prohibited from offering goods and/or services intended to be traded, prohibited from making or including standard clauses in each document and/or agreement if:

a. Declare the transfer of responsibility of business actors.

b. Stating that business actors have the right to refuse to return goods purchased by consumers.

c. Stating that business actors have the right to refuse to return the money paid for goods and/or services purchased by consumers.

d. Stating the granting of power of attorney from consumers to business actors either directly or indirectly to take all unilateral actions related to goods purchased by consumers in installments.

e. Regulates the matter of proving the loss of the use of goods or the use of services purchased by consumers.

f. Giving rights to business actors to reduce the benefits of services or reduce the assets of consumers who are the object of buying and selling services.

g. Stating that consumers are subject to regulations in the form of new, additional, continued and/or advanced changes made unilaterally by business actors when consumers use the services they buy.

h. Stating that the consumer authorizes the business actor to impose mortgage, lien, or security rights on goods purchased by consumers.

2. Business actors are prohibited from including standard clauses whose location or shape is difficult to see or cannot be read clearly, or whose disclosure is difficult to understand.

\footnotetext{
${ }^{24}$ Suharnoko, Hukum Perjanjian Teori dan Analisis Hukum, Prt. Ninth, Kencana, Jakarta, 2015, p. 65.

${ }^{25}$ Celina Tri Siwi Kristiyanti, Hukum Perlindungan Konsumen, Sinar Grafika, Jakarta, 2009, p. 139.

${ }^{26}$ Kelik Wardiono, Perjanjian Baku Klausul Ekseorasi dan Konsumen; Beberapa Uraian tentang Landasan Normatif, Doktrin, dan Praktiknya, Penerbit Ombak, Yogyakarta, 2014, p. 11.
} 
3. Every standard clause that has been stipulated by the business actor in the document or agreement that fulfills the provisions as referred to in paragraphs (1) and (2) is declared null and void.

4. Business actors are required to adjust standard clauses that are contrary to this law.

Based on the use of such standard clauses, in the implementation of the lease purchase agreement, there are also several clauses that contradict the prohibition on the use of standard clauses as stated in Article 18. Among these clauses in general it reads: "Furthermore, the Second Party gives full power to the First Party who, by virtue of its power of attorney with substitution rights, takes the vehicle belonging to the First Party, either at the place of the Second Party or at the place of another party who has rights from it." The existence of a clause that states the granting of full power of attorney to take the vehicle belonging to the first party, is actually contrary to Article 18 paragraph (1) letter d of Act No. 8 of 1999 concerning Consumer Protection which states that: "Business actors are prohibited from offering goods and/or services intended to be traded, prohibited from making or including standard clauses in every document and/or agreement if; states the granting of power of attorney from consumers to business actors either directly or indirectly to take all unilateral actions related to goods purchased by consumers in installments. There is one clause that contradicts Article 18 paragraph (1) letter d of Act No. 8 of 1999 concerning Consumer Protection certainly results in the enactment of paragraph (3) which states that every standard clause that has been stipulated by business actors in documents or agreements that meet the provisions as referred to in paragraphs (1) and (2) is declared null and void.

Regardless of this context, looking at the advantages and disadvantages of each agreement as described above, of course with the advantages and disadvantages of each agreement, at least it can be used as a reference regarding which agreement is better to implement in the community. . Especially when viewed from one of the objectives of Maqashidus Sharia is to protect assets. So, of course, it is certain to carry out an agreement that is more protective of both parties. Departing from that fact, the comparison between the lease purchase agreement and the Ijarah Muntahiya Bittamlik contract is important, so that no rights and obligations of both parties are injured. Moreover, seeing these two contracts have the same goal, namely the implementation of a lease that ends with ownership, then based on the advantages and disadvantages of the two contracts, it will certainly provide insight for the community to choose the best contract for the community. Moreover, it refers to the rules of Ushul Figh which states:

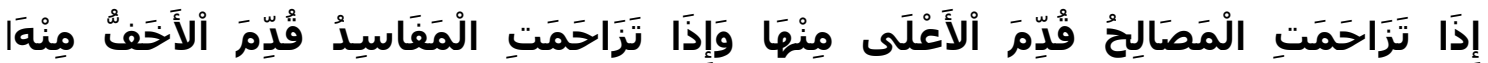

Which means: If there are several problems colliding, then the bigger (higher) benefit must take precedence. And if there are several Mafsadah (danger and damage) colliding, then the one chosen is the lightest Mafsadah.

Based on this rule, the existence of a lease and purchase agreement and an Ijarah Muntahiya Bittamlik contract, then the lease purchase agreement should not be allowed to be implemented. This is because apart from the fact that the lease and purchase agreement does not have clear rules in Indonesian positive law (because it is 
only based on the principle of freedom of contract), this agreement, as described above, also lacks legal certainty and has the potential to harm the buyer, because it can make withdrawals. Unilaterally which of course also contradicts Article 18 of the Consumer Protection Law. This is, of course, different from the Ijarah Muntahiya Bittamlik contract which already has legal certainty in Indonesian positive law. In addition, although the Ijarah Muntahiya Bittamlik contract is contrary to the nature of buying and selling at the end which is not binding, but in the settlement when there is a default by the buyer, directly based on the provisions must at least be resolved by the court. Based on this, then the Ijarah Muntahiya Bittamlik contract has more legal certainty, compared to a lease and purchase agreement.

\section{CLOSING}

A comparative study of the IMBT contract and the lease-purchase agreement states that the IMBT contract has more legal certainty than the lease-purchase agreement. This is because the IMBT contract has provisions regulated in the Sharia Banking Law, the Sharia Economic Law Compilation, and PSAK No. 107 on the accounting of Ijarah and Ijarah Muntahiya Bittamlik. This is different from the lease purchase agreement which is only based on the principle of freedom of contract, considering that the provisions regarding the lease purchase agreement have been revoked. On the other hand, the implementation of the Ijarah Muntahiya Bittamlik contract also has more legal certainty considering that efforts to resolve disputes in the Ijarah Muntahiya Bittamlik contract can be carried out through the provisions of Article 283 and Article 284 of the KHES by carrying out sales of the disputed object.

\section{REFERENCES}

Journals:

Husna Ni'matul Ulya, Penerapan Akad Ijarah Muntahiya Bittamlik (IMBT) Pada Transaksi Lembaga Keuangan Syariah, El-Wasathiya: Jurnal Studi Agama, Volume 6, Nomor 1, June 2018, p. 21-37

Panji Adam Agus Putra, Konsep Wa'ad dan Implementasinya dalam Fatwa Dewan Syariah Nasional Majelis Ulama Indonesia, Amwaluna; Jurnal Ekonomi dan Keuangan Syariah, Vol. 2, No. 2, p. 226.

Sentiya Dwi Ningsih, Peran Notaris Dalam Pelaksanaan Pembuatan Akta Akad Pembiayaan Di Bank Syariah Menurut Undang-Undang Nomor 2 Tahun 2014 Tentang Jabatan Notaris, Jurnal Akta Vol. 4. No. 1, March 2017, p.79-82

Books:

Abdul Aziz Khalifah al-Qishar, al-Ijarah Ma'aa Wa'du bi al-Tamlik li al-Dhihaabi wa alFidhdhah, (Kulliyatul al-Syariah, Jami'atul Kuwait, n.y)

Abdul Manan, Hukum Ekonomi Syariah: Dalam Perspektif Kewenangan Peradilan Agama, prt. Fouth, (Jakarta: Kancana, 2016)

Ahmad Khoirin Andi, Ijarah Muntahiya Bittamlik Sebagai Solusi Ekonomi Kerakyatan, ACTIVA: Jurnal Ekonomi Syariah, Volume 2 Nomor 22 October 2019

Ascarya, Akad dan Produk Bank Syariah, Prt. Fifth, Raja Grafindo Persada, Jakarta, 2015

Celina Tri Siwi Kristiyanti, Hukum Perlindungan Konsumen, Sinar Grafika, Jakarta, 2009 
Evi Ariyani, Hukum Perjanjian, Penerbit Ombak, Yogyakarta, 2013

Hasbi Ramli, Teori Dasar Akuntansi Syariah, Renaisan, Jakarta 2005

Jaih Mubarok, Fikih Mu'amalah Maliyah Akad Ijarah dan Jualah, Simbosa Rekatama Media, Bandung, 2017

Jeinal Bawarodi, Penerapan Perjanjian Sewa Beli di Indonesia dan Akibat Hukumnya, Lex Privatum, Vol. II, No. 3, 2014

Kelik Wardiono, Perjanjian Baku Klausul Ekseorasi dan Konsumen; Beberapa Uraian tentang Landasan Normatif, Doktrin, dan Praktiknya, Penerbit Ombak, Yogyakarta, 2014

Libertus Jaehani, Pedoman Praktis Membuat Surat Perjanjian Beserta Contohcontohnya, Prt. Second, Visimedia, South Jakarta, 2007

M Munir Fuady, Hukum Bisnis dalam Teori dan Praktik Buku Ketiga, Prt. Third, Pt. Citra Aditya Bakti, Bandung, 2017

Mahmud Abdul Karim Ahmad Irsyid, As-Syamil Fi Muamalat Wa amaliyatil Masharif alIslamiyah, Darun Nafais, Jordania, 2007

Muhammad Syafi'i Antonio, Bank Syariah dari Teori ke Praktik, Gema Insani, Jakarta

Nurul Qamar, Muhammad Syarif, dan Dachtran S. Busthami, Metode Penelitian Hukum (Legal Research Methods), Cv. Social Politics Genius, Makassar, 2017

Salim H.S., Perkembangan Hukum Kontrak Innominate di Indonesia, Prt. 11, Sinar Grafika, Jakarta

Sandrina Wijaya, Surat Perjanjian Bisnis Langsung Deal, Penerbit Pustaka Grathama, Yogyakarta, 2009

Soerjono Soekanto and Sri Mamudji, Penelitian Hukum Normatif (Suatu Tinjauan Singkat), Rajawali Pers, Jakarta, 2001

Suharnoko, Hukum Perjanjian Teori dan Analisis Hukum, Prt. Ninth, Kencana, Jakarta, 2015

Syaif Rajab Qazamil, al-Wa'du Bi al-Ta'aaqid (Diraasah Muqaaranah Baina al-Syariiati wa al-Qanuun), PDF

Regulation:

Fatwa DSN-MUI No. 27/DSN-MUI/III/2002 on al-Ijarah Muntahiya bi al-Tamlik. 